Revista Complutense de Educación

ISSNe: 1988-2793

http://dx.doi.org/10.5209/RCED.64579

\title{
Modelos de intervención socioeducativa
}

Autor: Martínez-Otero, V.

Editorial: Madrid: CCS

Año de publicación: 2018

$N^{o}$ de Páginas: 143

ISBN: 978-84-9023-918-6

"Modelos de intervención socioeducativa" es un libro actual al tiempo que tradicional. La educación social como profesión es relativamente nueva, pero la educación existe desde que el hombre es hombre, y por lo tanto, la educación social. En este sentido, coincido con P. Natorp en afirmar que toda educación es social o no es educación. Por otra parte, el campo de acción profesional de la educación social está tan interaccionado con otras profesiones sociales que necesita investigaciones serias para delimitarse y diferenciarse.

El presente libro es una investigación seria, un paso importante en la delimitación de este campo de acción tan unido a la esencia social del hombre. Constituye un aporte innovador para la formación y profesionalización del educador social. Fundamento esta afirmación en dos razones principales: A) Obtiene una síntesis del concepto de Pedagogía y de Pedagogía Social como ciencia y praxis de la educación $\mathrm{y}$, concretamente, de la educación-social que es el objeto de la Pedagogía Social. B) El análisis documentado y crítico que hace de la intervención socioeducativa y de los diferentes modelos que la activan contribuye a recuperar este proceso educativosocial del reduccionismo que asociaba el campo de acción del educador social a lo que pudiéramos denominar "síndrome del déficit". Síndrome que especializaba la intervención socioeducativa del educador social, limitándola a menores con problemas de conducta. Basta recordar que, durante años, su actividad se circunscribía a la reeducación de menores inadaptados, mal llamados delincuentes ("síndrome del déficit"). Este libro contrarresta el reduccionismo implícito en dicho síndrome, demostrando que la inadaptación social es un área más de intervención socioeducativa.

Existe hoy con relación a la "adaptación/inadaptación social" la tendencia a cambiar 'adaptación'/'integración social' como "acomodación a..." por el de "inclusión social”, con el fin de evitar la carga de pasividad que el término 'adaptación' acarrea. Este cambio terminológico enfatiza que el punto de referencia y protagonista de la inclusión es el sujeto y no la sociedad, siendo la inclusión un proceso activo de aprendizaje y de socialización por medio de la interacción, no una "acomodación a...".

El libro puntualiza que la intervención socioeducativa es un proceso educativo y social normalizado, aunque complejo, que requiere de la presencia profesional de los educadores sociales, dado que la sociedad junto con la escuela, la familia $\mathrm{y}$ otras instituciones han de converger en una acción coordinada. Complejidad y 
convergencia que el profesional de la educación social ha de tener en cuenta. Hacía falta profundizar en la intervención socioeducativa como una actividad normalizada de educación, y, como tal, mostrar que es un proceso centrado en la persona, y por lo tanto, asentar que las personas son los protagonistas activos de su propio proceso educativo-social, no la sociedad, la comunidad, la escuela, el profesor o el educador. El libro lo hace.

Como logro práctico, subrayo la identificación, análisis y sistematización de los siguientes modelos de intervención socioeducativa: modelo psicodinámico, modelo de modificación de conducta y modelo cognitivo, modelo cognitivo-conductual, modelo de intervención en crisis, modelo centrado en la tarea, modelo humanista, modelo crítico, modelo sistémico.

El desarrollo de una teoría para la práctica es un gran logro teórico. Insiste el autor en que la intervención socioeducativa no es simple práctica social sin base teórico-científica. Por consiguiente, tanto en el caso de disciplina curricular como en el de praxis, necesita método, pero este requiere un marco paradigmático que lo fundamente y le sirva de guía para desplegar y organizar la acción socioeducativa.

Resumo las principales claves identificadoras de esta teoría para la práctica en:

1. Perspectiva humanista del concepto de intervención socioeducativa. Una interpretación superficial del humanismo puede llevar a la idea errónea de que humanismo implica excluir técnica y eficacia de la intervención socioeducativa. Técnica no se opone a humanismo. El humanismo busca eficacia, pero la eficacia no la mide por parámetros externos a la persona que se educa, sino, como clarifica el autor, por el éxito de su desarrollo personal como persona humana y en cuanto humana. Insiste el autor, en que, desde una perspectiva humanista, la relación entre el profesional y la persona destinataria de la intervención requiere ciertamente método, pero un método basado en la comprensión y la interacción donde el abordaje técnico no puede caminar al margen de la ética.

La superficialidad e inversión de valores del funcionalismo actual queda al descubierto en la perspectiva humanista, puesto que, en el funcionalismo, la persona deja de ser el principal valor y fin de la educación para ser substituido por la voraz dinámica de la eficacia económica. El autor no cuestiona la técnica, pero insiste: ésta no puede llevarse a cabo al margen de la ética. Afirma que el fin de la educación es de la propia persona que se educa, es su vida, no la academia ni el trabajo al margen de ésta.

2. Planteamiento profundo del tema de los valores. Analiza de forma serena y equilibrada los riesgos del subjetivismo y del objetivismo.

3. Generador de ideas que ayudarán a los investigadores educativo-sociales y a los educadores sociales en la implementación de un código ético.

Si el análisis crítico del libro lo hacemos desde un didactismo sesgado por funcionalismos tecnológicos, podría decirse que es un libro denso y duro. Tal vez, pues es fruto de larga investigación. Por el contrario, si lo hacemos desde la didáctica como procedimiento instrumental de ayuda a la persona que aprende, habría que decir que el libro es positivamente didáctico, porque cuestiona, hace pensar, genera dudas, ofrece información profunda, principios, ideas, análisis y síntesis valiosas y actuales, valores, bases para valorar, procedimientos, etc. que necesitan ser comple- 
tados con la ayuda del profesor. Sirve como manual online que no da todo hecho a los aprendices, como es el caso de algunos, mal llamado manuales online, sino documentación y cauces para el aprendizaje crítico y creativo.

Considero, en suma, que el libro constituye una investigación seria y un paso importante para la formación y la profesionalización del educador social.

José Vicente Merino Fernández Catedrático de Pedagogía Social. UCM merino@ucm.es 